\title{
Biodegradation of Agricultural Residues and Oily Waste, Their Effect on Vegetable Crop Yield
}

\author{
S. V. Kakde (M.Sc Microbiology) \\ Agnihotri College of Science and Biotechnology Research Centre, Wardha \\ Affiliated to RTM Nagpur University, Nagpur-Maharashtra
}

\begin{abstract}
Biodegradation is the breakdown or transformation of chemical substances by microorganisms using substance as a carbon source or energy source. Biodegradation means decomposition of agricultural residues and oily waste carried out. Where the nitrogen content was increased from $75 \%$ to $1.23 \%$ in $100 \%$ agricultural compost and positive effect of oily waste was the requirement of extra humidity due to the hydrophobic property of the specific waste. Agricultural residues and oily waste act as a bulking agent which can be decomposed by cow manure for composting. Compost is the secret ingredient that allows bacteria to work having some kind of growth medium which require to micro-organisms. Composting is the enrichment technique adopted by two method aerobic and anaerobic composting seven treatment in each method. Aerobic and anaerobic composting requires 120 days and 150 days for degrading respectively. As the less time period and to avoid the problem of odor we adopted method of aerobic composting .the effect of compost in the field trial results of spinach crop could be experimented. Field trial experiment carryout by duplicate method because effect of soil, effect of bioinoculum and the method of composting affect production of crop.
\end{abstract}

Keywords: Biodegradation, Decomposition, Composting, Agricultural residues, oily waste, etc

\section{Introduction}

Biodegradation of agricultural waste like sugarcane leaves, soyabean straw, wheat straw, cotton stalked is a serious problem in indianite is very essential to develop a strategy to these waste.(K.Jeevan Rao,2007) Most of the time these waste product are burned in the field but, burning of these agricultural residues lead to the emission of harmful gases such as $\mathrm{CO}_{2}, \mathrm{CO}, \mathrm{NO} 2$, etc lead to pollution and also effect on the ozone layer or sometime it is dumped in the remote area which also lead to foul odor which cause the spread of many diseases in the surrounding area. $\left(18^{\text {th }}\right.$ World congress of social science,2006)

These agricultural wastes can be decomposed or biodegrade completely in less time is possible by a method known as composting. This is an ecofriendly method in which many microbes and organism present in nature are used to carry out degradation of agricultural waste. Bacteria especially fungi can carryout the decomposition process at faster rate because fungi have capacity to digest the wood.(BettsWB,et al,1988) Lignin is the complex with the cellulose present in wood is difficult to degrade but fungi have ability to degrade it.

Biological treatment of agricultural residues is a new method for improve digestibility other bacteria have an important role in increasing their digestibility.(A.A.Safari sinegani,2005).fungal species such as Aspergillus, Penicillium, Tricoderma plays important role in the decomposition of various kind of waste material .Fungi are responsible for decomposing more than $80 \%$ of the cellulose. Cellulose is the most abundant polymer on the earth.(Betts WB et al 1988)composting is the most enrichment technique used for the evaluation of large quantity of agricultural waste. This is done under two method aerobic and anaerobic method.
This enrichment technique is adopted with two methods and seven treatments in each method. Organic material undergo decomposition under thermophilic and mesophilic condition in heap, pits polythene bags or tanks with moisture and aeration and the final byproduct is dark brown color material called compost.

1.1The humification of organic material under most condition occurs in three stages:

1) Mesophilic stage: This is the first step of degradation which is occurring for a week. This is the exothermic process and may cause increase in temperature by $40{ }^{\circ} \mathrm{C}$

2) Thermophilic stage: this is the second step of degradation lasting for about two week .during this stage the temperature arises to about 50-70 ${ }^{0} \mathrm{C}$.such a drastic increase in temperature is accompanied by decomposition of cellulose which is present in the agricultural waste and raw material.

3) Curing stage: This is the third stage in which the temperature decreases and the material get composted. At this stage the proper degradation of raw material and compost preparation start. Mesophilic organism able to recognize it which often produce compound useful for plant growth.

Composting is the easy way of reused or recycles the raw material in the field. Composting is a natural biological process controlled decay of organic matter in a warm moist environment by action of bacteria or fungi. (Salvator and sabee, 1995)As this natural process do gently it is beneficial for increase the soil fertility and also help in increase the yield of crop without using the chemical fertilizers in soil which is give innovation for "ORGANIC FARMING".

Cowdung manure is a nitrogen rich material used for decomposition of raw material because it containing many species of fungi such as Aspergillus niger, Aspergillus flavus .Cowdung manure use for the composting used for the 


\section{International Journal of Science and Research (IJSR) \\ ISSN (Online): 2319-7064}

Index Copernicus Value (2015): 78.96 | Impact Factor (2015): 6.391

supply N, P, K, Ca and C. Large no. of micro-organism present in the compost known as the physical decomposer that can chew and grid the raw material for the preparation of compost (Stainer et all, 1988). The biodung compost technique is based on the bioconversion of green biomass and agricultural residues in the useful product which are not commonly consumed by farm animals.

\subsection{Factors controlling the process of composting:}

\subsubsection{C: $\mathrm{N}$ ratio}

The process of conversion organic material into organic manure is the chiefly microbiological that can be influenced by the proportion of carbaneous and nitrogenous material that are present in the organic waste. It is observed that $\mathrm{C}: \mathrm{N}$ of 30 is the most favorable of most of the raw material. When the organic compound containing less percent of nitrogen the $\mathrm{C}$ : $\mathrm{N}$ ratio is more such as cereals residue of wheat soya bean, Jawar, Bajra, Maize etc

\subsubsection{Moisture}

Moisture of decomposing organic material should maintain around $50-55 \%$.Moisture percent less than $30 \%$ residues the microbial activity and slows down the process of composting. In aerobic condition, during the period of decomposition oxygen get dissolved in water which results in bad odor and incomplete decomposition.

\subsubsection{Aeration}

It is essential to maintain proper aeration .The oxygen concentration considered adequate is about $10-15 \%$. As the decomposition of raw material occur oxygen is essential in both the aerobic and anaerobic process. Micro-organism help in the decomposition they get energy from the contaminated to an electron acceptor i.e. Oxygen. They invest their energy to produce more cells with some electron and carbon from the contaminant.

\subsubsection{Temperature}

Temperature of the compost increases to $50-55^{0} \mathrm{C}$, after $2-5$ days of composting. There is need of high temperature because at $55^{\circ}$ and above temperature pathogens get destroyed For the regulation of decomposition turning and aeration is necessary high temperature indicate that the decomposition process is in the progress which can make good quality compost and free from pathogens

\subsection{5 $\mathrm{P}^{\mathrm{H}}$}

The $\mathrm{P}^{\mathrm{H}}$ of the compost is slightly acidic in nature i.e. 6.0.At the early stage there is production of organic acid hence $\mathrm{P}^{\mathrm{H}}$ goes again acidic 4.5-5.0 As the temp goes to increase it get converted in to alkaline $\mathrm{P}^{\mathrm{H}}$ 7.5-8.5.The $\mathrm{P}^{\mathrm{H}}$ of the mature compost is $7.5-8.5$.

\subsection{Chemical parameter for judging the quality of compost}

1.3.1 Determination of nitrogen $(N)$ : Estimation of nitrogen from the compost takes place by two method mainly Dumas method and Kjeldahl method. In Dumas method estimation is carried out by taking sample in gaseous from and in kjeldahl method estimation is carried out by converting the Nitrogen in the sample (compost)in ammonia and then into ammonium sulphate. In biodegradation the percentage of nitrogen get increased from 30 days to 120 days as the compost get matured

\subsubsection{Determination of phosphorous $(P)$}

Determination of phosphorous in the compost takes place by Vanado-molybdo phosphate yellow color method. In this method phosphorous in the compost get react with vanadate and molybdate and from yellow color. Color develop in about $30 \mathrm{~min}$ and get stable for about 2-8 week.Thid method is very advantageous because of its simplicity. The percentage of nitrogen also increased after 120 days as compare to 30 days.

1.3.3 Determination of potassium (K): estimation of potassium from the compost takes place by acid digestion method using flame photometer. The percentages of potassium also increased as the compost get matured within 4 month after 120 days by 30 days percent.

1.3.4 Determination of $\operatorname{carbon}(\mathbf{C})$ : determination of carbon can be takes place by treating the compost with $\mathrm{K}_{2} \mathrm{Cr}_{2} \mathrm{O}_{7}$ in the presence of $\mathrm{H}_{2} \mathrm{SO}_{4}$ where oxidation of carbon occurs following reaction takes place (Walkley, J and Riley, J. P. 1962)

$\mathrm{K}_{2} \mathrm{Cr}_{2} \mathrm{O}_{7}+4 \mathrm{H}_{2} \mathrm{SO}_{4} \rightarrow \mathrm{K}_{2} \mathrm{SO}_{4}+\mathrm{Cr}_{2}\left(\mathrm{SO}_{4}\right)_{3}+4 \mathrm{H}_{2} \mathrm{O}+3 \mathrm{O}$

$3 \mathrm{C}$ (organic carbon) $+6 \mathrm{O} \rightarrow 3 \mathrm{CO}_{2}$

The main aim of this topic is to reused agricultural residues and oily waste from the oily refinery which is the most interesting research subject of the environmental and social science. These waste has been discuss in the news letter, industrial article, News report ,television program which has been increased awareness of it as a public issue.

\section{Materials and Method}

\subsection{Collection of raw materials}

\subsubsection{Collection of agricultural waste:-}

The agricultural waste collected from Mr.Patni farm, Sindhi Meghe Wardha. The collected agricultural wastes as wheat straw and soybeans straw. These two are lignocellulosic waste containing phosphorous and potassium.

\subsubsection{Collection of oily waste:-}

Oily waste was collected from the oil refinery company situated at Gopuri in Wardha city. Groundnut cake was taken as oily waste which containing high percentage of nitrogen.

\subsubsection{Collection of composting manure:-}

Composting manure collected from nearby dairy farm. These collected cowdung manure used for carryout decomposition of agricultural and oily waste.

\section{2 weighing of raw materials}

The collected raw material weighs properly for the further protocol singly each raw material was taken in proportion of $1 \mathrm{Kg}$

\subsection{Mixing of raw materials}

\section{Volume 6 Issue 7, July 2017 www.ijsr.net}




\section{International Journal of Science and Research (IJSR) \\ ISSN (Online): 2319-7064}

Index Copernicus Value (2015): 78.96 | Impact Factor (2015): 6.391

All the collected raw materials are mixed as per the following protocol .Each treatment is carryout in duplicate manner as per the following protocol:-

$\mathrm{T} 1=$ wheat straw + Cowdung

$\mathrm{T} 2=$ Soyabean straw + Cowdung

$\mathrm{T} 3=$ Groundnut cake + Cowdung

$\mathrm{T} 4=$ Groundnut cake + Wheat straw + Cowdung

$\mathrm{T} 5=$ Wheat straw + Soyabean straw + Cowdung

T6 $=$ Groundnut cake + wheat straw + Soyabean straw +

Cowdung

$\mathrm{T} 7=$ Groundnut cake + Soyabean straw + Cowdung

\subsection{Biodegradation / Decomposition period}

According to protocol described in different combination raw materials were mixed and kept in clean polythene bags to carry out its decomposition. The polythene bags were kept under tree shed at Mr.Patni's farm, Sindhi Meghe, Wardha.

After mixing of raw materials the actual decomposition start after 10-15 days this can be determine by daily recorded the temperature status of each treatment for 10-15 days. According to the prevails research work; temperature increases in initial days and followed by decreases in temperature observed. It is assumed that the actual decomposition start when temperature suddenly decreasing.

\subsection{The temperature variations of each treatment are as} showed by following graph

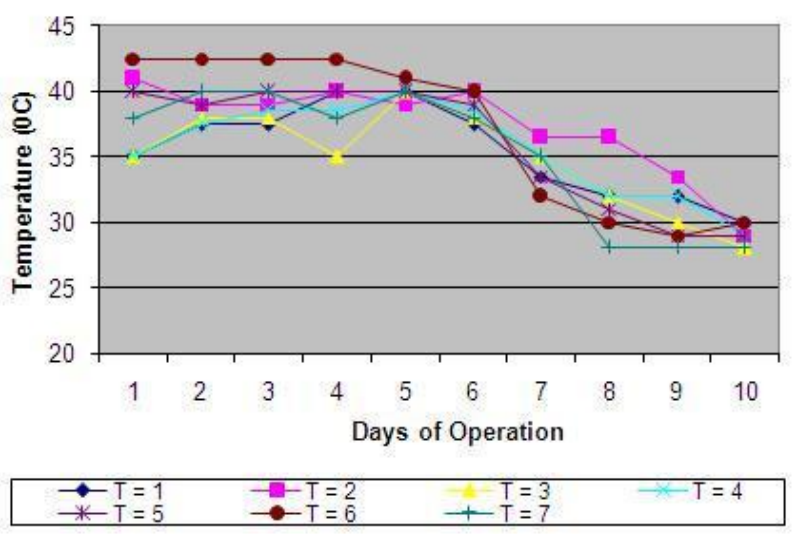

\subsection{Physical and chemical analysis of raw material}

A Physical and chemical analysis of each raw material used like wheat straw, soya bean straw, cow dung and groundnut cake was carried out by determining the $\mathrm{N} \%, \mathrm{P} \%, \mathrm{~K} \%$ and $\mathrm{C} \%$ percentage present in them.

\subsection{Analysis of each treatment after 120 days of mature compost.}

2.7. a. Physical characteristics of compost.

2.7. b. Chemical characteristics of compost.

2.7. c. Microbial characteristics of compost.

\section{Results and Discussion}

\section{Compost preparation}

Very good compost was prepared from agricultural residues and oily waste within 120 days. The compost produced was dark brownish to black in color with earthy smell. The compost was sieve to separate the decomposed organic materials. On an average $1.5 \mathrm{~kg}$ of sieved compost was produced.

\section{Observation}

Table 4.1: Reduction in Weight of prepared compost:

\begin{tabular}{|l|l|l|l|l|}
\hline $\begin{array}{c}\text { Sr. } \\
\text { No }\end{array}$ & Treatment & $\begin{array}{c}\text { Initial } \\
\text { Weight } \\
\text { (gms) }\end{array}$ & $\begin{array}{c}\text { Final } \\
\text { Weight } \\
\text { (gms) }\end{array}$ & $\begin{array}{c}\% \text { of } \\
\text { reduction } \\
\text { in weight }\end{array}$ \\
\hline 1. & Treatment-1 & 2000 & 1200 & $40 \%$ \\
\hline 2. & Treatment-2 & 2000 & 1500 & $25 \%$ \\
\hline 3. & Treatment-3 & 2000 & 225 & $88.75 \%$ \\
\hline 4. & Treatment-4 & 3000 & 2100 & $30 \%$ \\
\hline 5. & Treatment-5 & 3000 & 1900 & $36.67 \%$ \\
\hline 6. & Treatment-6 & 3000 & 2000 & $33.34 \%$ \\
\hline 7. & Treatment-7 & 4000 & 3750 & $6.25 \%$ \\
\hline
\end{tabular}

From the above observation of table.1; it was found that reduction take place in each treatment. From the initial and final weight of the compost prepared we calculated total reduction percentage for each treatment. In the treatment-3, where compost was prepared from the combination of groundnut cake and cow dung causing highest percentage of reduction i.e. $88.75 \%$ after 120 days of decomposition period So, that this treatment was discarded and not used for field application.(Because 500 gms apply to each plot during field trial) In treatment-7 percentage of reduction was less i.e.6.25\% which prepared from combination of wheat straw, soya bean straw, groundnut cake and cow dung. Thus, only treatment 1, 2, 4, 5, 6 and 7 were selected for field trial.

Table 4.2: Physical parameters of prepared compost are as follows

Color - Black, Brown

Odor - Earthy

Solubility - Insoluble

\begin{tabular}{|c|c|c|c|c|}
\hline Sr. No. & Treatment & Moisture \% & PH & EC \\
\hline 1. & T-1 & 11.2 & 7.20 & 0.486 \\
\hline 2. & T-2 & 09 & 7.24 & 0.493 \\
\hline 3. & T-3 & 03 & 8.64 & 0.356 \\
\hline 4. & T-4 & 12.62 & 6.19 & 0.489 \\
\hline 5. & T-5 & 10.11 & 6.70 & 0.418 \\
\hline 6. & T-6 & 15.42 & 7.40 & 0.431 \\
\hline 7. & T-7 & 19.8 & 7.2 & 0.364 \\
\hline
\end{tabular}

Source: these results are obtained from the actual analysis of sample carried out at soil and compost testing laboratory of Dharamitra, Wardha.

$\mathbf{P}^{\mathrm{H}:}$ Biodegradation can occur under a wide range of $\mathrm{pH}$ of 6.5 to 8.9 is generally optimal for biodegradation and with this reference in observation table 2 , it was found that the $\mathrm{pH}$ ranges from 6.1-8.6.pH may affect the availability of nutrient. T -1, T-2 and T- 7 has optimal $\mathrm{pH}$ value i.e. 7.20, 7.24 and 7.2 respectively. Whereas Treatment No.3 had highest $\mathrm{pH}$ value 8.64 . 


\section{International Journal of Science and Research (IJSR) \\ ISSN (Online): 2319-7064 \\ Index Copernicus Value (2015): 78.96 | Impact Factor (2015): 6.391}

Similar type of work carry out on biodegradation by Jakson et al(1973) where he used agricultural waste, in his experiment he observed that the initial $\mathrm{pH}$ value of agricultural waste ranges from 7.8-8.9 and they show decreases in advancement in period of composting from 30 days to 120 days in all the treatment of aerobic compost.

According to my observations in my experiment agricultural residues were mixed in different combination kept for biodegradation showed good $\mathrm{pH}$ range from 6-1-8.6 similar results obtained by Jackson (1973) i.e.6.5-8.5

Moisture: Moisture influences the rate of microbial population which helps in faster and proper degradation .From observation table 2, the T-1,T-4,T-5,T-6,T-7 had highest percentage of moisture i.e.11.2, 12.62, 10.11, 15.42, $19.8 \%$ respectively and $\mathrm{T}-2$ and $\mathrm{T}-3$ had least moisture content i.e. 09 and $03 \%$.hence it was considered that T-1,T$4, \mathrm{~T}-5, \mathrm{~T}-6, \mathrm{~T}-7$ had containing more microbial population as compare to the $\mathrm{T}-2$ and $\mathrm{T}-3$

Moisture influences the rate of contaminant metabolism because it influences the kind and amount of soluble material that are available as well as the osmotic pressure. As mentioned above Dr.R.K.Pathak gave the information about the moisture that why moisture is necessary where in case of moisture organic affects the exchange of oxygen. Under aerobic composting, oxygen can be consumed faster than the anaerobic composting, oxygen can be consumed faster than it is replenished in the solid vapor space and organic bed become anaerobic .This can retard the rate of biodegradation and causes change in microbial metabolic activity.

Electrical conductivity (EC) : According to prevail research electrical conductivity of the degraded raw material decreases in the final state as compare to initial stage due to high microbial activity and minralization.In later stage humification proceed the humic fraction might be complexed with the soluble salts and then decrease in the EC takes place. With this reference in the observation table 2 , it was found that T-3 and T-7 had very low percentage of electrical conductivity as compare to other treatment. But T3 gets discarded because of higher reduction percentage hence; treatment-7 (EC-0.394\%) was selected as a best combination for compost.

Similar type of biodegradation work carry out by Jeevan Rao et al in (2007) where he carryout the work on decomposition of urban solid waste in combination with agricultural waste .In his experiment he found that EC was maximum after the 30 days of decomposition and then decreases up to 120 days where in his results EC ranges from $0.32-0.45 \mathrm{dSm}^{-1}$ in my experimental work of mature compost from $0.35-0.49 \mathrm{dSm}^{-1}$

The above results for the $\mathrm{p}^{\mathrm{H}}$, Moisture and electrical conductivity also matches the results given by the research analysis carried out by MGIRI, wardha and gave the standards report for the quality of compost given below:
Table 4.3: Chemical analysis of the initial raw materials is as follows:

\begin{tabular}{|c|c|c|c|c|}
\hline $\begin{array}{c}\text { Sr. } \\
\text { No }\end{array}$ & Sample details & Nitrogen\% & $\begin{array}{c}\text { Phosphorous } \\
\%\end{array}$ & Potassium \% \\
\hline 1. & Wheat straw & 1.0 & 1.5 & 1.3 \\
\hline 2. & Soya bean straw & 1.5 & 1.3 & 1.2 \\
\hline 3. & Groundnut cake & 0.5 & 0.15 & 0.8 \\
\hline 4. & Cow dung & 1.0 & 1.0 & 1.5 \\
\hline
\end{tabular}

This analysis was done only to know the initial nutrient status of raw material

Table 4.4

\begin{tabular}{|c|c|c|c|c|c|}
\hline $\begin{array}{c}\text { Sr. } \\
\text { No }\end{array}$ & Treatment & $\begin{array}{c}\text { Nitrogen } \\
\%(\mathrm{~N})\end{array}$ & $\begin{array}{c}\text { Phosphorous } \\
(\mathrm{P})\end{array}$ & $\begin{array}{c}\text { Potassium } \\
\%(\mathrm{~K})\end{array}$ & $\begin{array}{c}\text { Carbon } \\
\%(\mathrm{C})\end{array}$ \\
\hline 1. & $\mathrm{~T}-1$ & 1.93 & 0.156 & 0.098 & 12.11 \\
\hline 2. & $\mathrm{~T}-2$ & 1.28 & 0.131 & 0.102 & 10.96 \\
\hline 3. & $\mathrm{~T}-3$ & 0.89 & 0.102 & 0.104 & 11.89 \\
\hline 4. & $\mathrm{~T}-4$ & 1.07 & 0.167 & 0.096 & 12.09 \\
\hline 5. & $\mathrm{~T}-5$ & 1.49 & 0.114 & 0.102 & 10.56 \\
\hline 6. & $\mathrm{~T}-6$ & 1.25 & 0.198 & 0.107 & 12.24 \\
\hline 7. & $\mathrm{~T}-7$ & 2.99 & 0.199 & 0.114 & 9.04 \\
\hline 8. & Mean & 1.547 & 0.1524 & 0.1033 & 11.27 \\
\hline
\end{tabular}

Chemical analysis of each treatment after 30 days

Table 4.5: Chemical analysis of each treatment (Matured compost) after 120 days

\begin{tabular}{|c|c|c|c|c|c|}
\hline $\begin{array}{c}\text { Sr. } \\
\text { No }\end{array}$ & Treatment & $\begin{array}{c}\text { Nitrogen } \\
\%(\mathrm{~N})\end{array}$ & $\begin{array}{c}\text { Phosphorous } \\
(\mathrm{P})\end{array}$ & $\begin{array}{c}\text { Potassium } \\
\%(\mathrm{~K})\end{array}$ & $\begin{array}{c}\text { Carbon } \\
\%(\mathrm{C})\end{array}$ \\
\hline 1. & $\mathrm{~T}-1$ & 1.78 & 0.217 & 0.134 & 10.98 \\
\hline 2. & $\mathrm{~T}-2$ & 0.89 & 0.211 & 0.131 & 10.57 \\
\hline 3. & $\mathrm{~T}-3$ & 0.76 & 0.193 & 0.129 & 11.32 \\
\hline 4. & $\mathrm{~T}-4$ & 0.86 & 0.210 & 0.139 & 11.88 \\
\hline 5. & $\mathrm{~T}-5$ & 1.23 & 0.211 & 0.135 & 10.43 \\
\hline 6. & $\mathrm{~T}-6$ & 0.45 & 0.213 & 0.143 & 11.98 \\
\hline 7. & $\mathrm{~T}-7$ & 1.78 & 0.219 & 0.198 & 7.25 \\
\hline 8. & Mean & 1.10 & 0.2105 & 0.144 & 10.63 \\
\hline
\end{tabular}

From table: 4 and table: 5, this research analysis was conducted for decomposition of agricultural waste and oily waste and use this compost as fertilizer for crop. Seven treatments were done to determine the effect decomposition of organic waste. This investigation aim to study the reduction in organic carbon and status nutrients like $\mathrm{N}, \mathrm{P}, \mathrm{K}$ and certain characteristic of compost produce.

\section{Organic carbon}

The critical appraisal data available on organic carbon content in the decomposition of the agricultural waste based on the analysis of percentage of reduction in organic carbon observed after comparing table 4 with table; 5 after 30 days and after 120 days as compare to initial carbon content at 30 days reduction in organic carbon is observed in all treatment. Total carbon content after 30 days of all treatment was $11.27 \%$ and after 120 days of decomposition it get reduced to $10.62 \%$.Because same experiment carry out by Dr. R. K. Pathak (2010) in their experiment where he carryout the chemical characterization of prepared compost where they observed that there is reduction in carbon percentage in aerobic composting where the percentage of carbon reduces from 58.075-51.25 similarly in case of my experimental work percentage of carbon reduces 11.27-10.62\% 


\section{International Journal of Science and Research (IJSR) \\ ISSN (Online): 2319-7064}

Index Copernicus Value (2015): 78.96 | Impact Factor (2015): 6.391

\section{Total Nitrogen}

From the observation table 4 and table 5 reduction in percentage nitrogen takes place in all treatment on 30 days of decomposition \% of $\mathrm{N}$ was 1.547 and for 120 days it was $1.10 \% \mathrm{~T}-1, \mathrm{~T}-2$ and T-5. i.e. $1.93-1.78,1.98-0.89$ and 1.491.23. Where there is no readily available source of nitrogen the percentage of the reduction of nitrogen obtained is obtained very less in treatment no. 7 i.e.2.99-1.78 That was because this treatment contain all the organic matter containing bacterial and fungal species which lead to greater consumption of the nitrogen during initial stage of growth . The amount of nitrogen in the compost decreases with the succession of the process.

This behavior is attributed to the action of microbes as during initial dose decomposition of microbes utilizes the readily available nitrogen from the raw material for their growth and thus for building of cells and protein in their body. Hence the reduction in nitrogen takes place in all treatment except those treatment which do not containing groundnut cake.

In the decomposition of agricultural waste Jeeven Rao et al in his experiment found that nitrogen content was decreases from $1.29 \%-0.85 \%$ from 30 days to 120 days similarly in my experiment reduction in nitrogen content takes place where nitrogen content reduces from 1.547-1.25\%

\section{Total phosphorous}

The analysis data showed that irrespective that of treatment their gradual increase in $\mathrm{P}$ content as the process goes on progressively. From the analysis of all treatment it was observed that in there is increase in phosphorous percentage in all treatment i.e. $0.1254-0.2105 \%$

After comparing observation table 4 with table 5 similar type of result obtained by jeeven Rao et al same reaction was takes place where he found that increase in \% of phosphorous after comparing compost of 30 days with the compost of 120 days. The increase in \% of phosphorous was noted $1.45-1.48 \%$.

\section{Total potassium}

From the study of previous research experiment it was concluded that the percent of potassium increases as decomposition process progressively goes on. In the analyzed data it was observed that the percentage potassium at 30 days it was $0.1033 \%$ and after 120 days it was $0.1441 \%$ hence total increases in phosphorous content was $0.0408 \%$.

According to this report by Jeeven Rao et al same process was carryout where from the initial days to final days potassium percentage was increased from1.07-1.10.hence we conclude that percentage of potassium increases as the process of decomposition proceed. Thus after taking various parameters i.e. physical, chemical and microbiological whatever results obtained it was seen that there was a successful degradation of various agricultural residues and oily waste takes place.
Table 4.6: The microbial analysis of the prepared mature compost is as follows

\begin{tabular}{|c|c|c|c|}
\hline Sr. No. & Treatment & $\begin{array}{c}\text { Bacterial Count } \\
(\text { CFU/ml) }\end{array}$ & $\begin{array}{c}\text { Fungal Count } \\
(\text { CFU/ml })\end{array}$ \\
\hline 1. & Treatment-1 & $210 \times 10^{9}$ & $44 \times 10^{4}$ \\
\hline 2. & Treatment-2 & $160 \times 10^{9}$ & $33 \times 10^{4}$ \\
\hline 3. & Treatment-3 & $130 \times 10^{9}$ & $28 \times 10^{4}$ \\
\hline 4. & Treatment-4 & $187 \times 10^{9}$ & $26 \times 10^{4}$ \\
\hline 5. & Treatment-5 & $215 \times 10^{9}$ & $42 \times 10^{4}$ \\
\hline 6. & Treatment-6 & $192 \times 10^{-9}$ & $37 \times 10^{4}$ \\
\hline 7. & Treatment-7 & $267 \times 10^{-9}$ & $46 \times 10^{4}$ \\
\hline
\end{tabular}

Loss of moisture had direct reflection on reducing microbial count.i.e bacterial count and fungal count those treatment which had more moisture percentage that treatment containing more microbial population from the observation of table 2 T-1,T4,T-5,T-6 and T-7 had more percentage of moisture i.e11.2, 12.62, 10.11, 15.42 and19.8 respectively as compare to T-2 and T-3(moisture 09 and $03 \%$ respectively).from the observation table $6 \mathrm{~T} 1, \mathrm{~T}-5$ and T-7 shows highest bacterial and fungal population as given. $210 \times 10^{9}, 215 \times 10^{9}, 267 \times 10^{9}$ and $44 \times 10^{4}, 42 \times 10^{4}, 46 \times 10^{4}$ respectively.treatment 7 shows highest microbial population as compare to T-1 and T-5.So, it was considered that the T-7 is the enriched treatment for microbial population. Which directly effect on yield. T $\left(267 \times 10^{9}\right.$ and $\left.46 \times 10^{4}\right)$.

Table 7: Effect of prepared compost treatments on vegetative growth of plant

\begin{tabular}{|c|c|c|c|c|c|}
\hline S No & Treatments & $\begin{array}{c}\text { Shoot } \\
\text { length } \\
\text { Cm }\end{array}$ & $\begin{array}{c}\text { Root } \\
\text { length } \\
\text { Cm }\end{array}$ & $\begin{array}{c}\text { Branching } \\
\text { Cm }\end{array}$ & $\begin{array}{c}\text { Total } \\
\text { yield } \\
\text { Gms }\end{array}$ \\
\hline 1. & Treatment-1 & 15.8 & 6.6 & 8 & 612.5 \\
\hline 2. & Treatment-2 & 13.8 & 6.2 & 7 & 570 \\
\hline 3. & Treatment-4 & 14.5 & 5.7 & 9 & 480 \\
\hline 4. & Treatment-5 & 15.4 & 7.4 & 8 & 880.5 \\
\hline 5. & Treatment-6 & 12.7 & 6.0 & 7 & 772.5 \\
\hline 6. & Treatment-7 & 16.5 & 7.5 & 8 & 988.7 \\
\hline 7. & Control & 13.1 & 5.3 & 5 & 600 \\
\hline 8. & Chemical fertilizer & 16.4 & 6.5 & 6 & 970 \\
\hline
\end{tabular}

The prepared compost was selected to study the effect of compost on spinach crop yield. The following parameters were selected to study the effect of different treatment on the growth of spinach. Vegetative growth of spinach as follows. The following table reveals that spinach sown in the plots in duplicate manner by using compost prepared from each seven treatment of compost. Vegetative growth and more yield was compared from the growth of each treatment of spinach with chemical fertilizer and control plot. [See table: 7]

From the below observation table 7 on the basis of total yield of the spinach crop was observed more in chemical fertilizer treated plot i.e. $970 \mathrm{Gms}$. But it was also observed that T-5 and T-7 treated plot also showed good yield which was nearly show similarity with chemical fertilizer treated plot.i.e.880.5 and 988.7 gms respectively. So, T-5 and T-7 both the treatment gave good yield as compare to control plot and shows similarity with chemical fertilizer treated plot. Hence we suggested these use of these combination treatment as compost. But we know chemical fertilizer increase the crop productivity but on other hand adversely affect on soil fertility .So that in the field trial experiment 


\section{International Journal of Science and Research (IJSR) \\ ISSN (Online): 2319-7064}

Index Copernicus Value (2015): 78.96 | Impact Factor (2015): 6.391

prepared compost from agricultural waste compared with chemical fertilizer.

\section{Conclusion}

The conclusion drawn on the basis of results obtained for various parameters showed that treatment showed that T-7 was the most significant with respect to other treatment .In this treatment the percentage of nitrogen, total nitrogen percentage was found to be greater as compared other treatment .along with carbon and nitrogen which form the primary nutrients. Also, estimation of $\%$ of phosphorous as well as $\%$ of potassium was carried out showed significant increase in them. These nutrients are essential to plant after carbon and nitrogen.

Regarding the disposal of ever increasing amount of agricultural wastes is becoming aserious problem in many developed countries. Thus recycling of these waste to its maximium potential for compost preparation is a best solution /remady on this problem . This will not only solve the waste management problem .This will not the shortage of fertilization for marginal and small farmer. The prepared compost proved to improved soil fertility.

The study reveals that there is production of matured and quality compost from agricultural waste on the basis of nutrients status of compost and its field trial; which gives remarkable increase in spinach yield as compare to control. Also it is concluded on the basis of observation table 6 that the utilization of agriculture and oily waste material along with bioinoculums to prepare the compost should be a good alternative for the chemical fertilizer gives good yield; are highly soluble in water are destructive to earthworms and microorganisms

The study showed a good approach to add up value or attention towards the utilization of different type of agricultural waste.

\section{Application}

1) As this process was found to be successful in degrading agricultural organic waste, similarly it is estimated to be effective for household and other garden generated day to day.

2) It is simple process and does not require much space and economic involvement it can be carried out at home or in garden with daily refuse. The degraded matter thus obtained can be use as fertilizers for the garden plant.

3) The degraded matter formed is nothing but compost which can benefit soil and plant in many ways.

4) It increases the soil organic matter content and its moisture holding capacity as well as provides wide variety of essential nutrient to the crops or plant.

5) The essential nutrient can be added to the agricultural waste obtained and after degradation it can be used as enriched compost for the plant.

6) This process is optimized and this can be made available to farmers as fertilizer at cheaper rate in an environment friendly way and even the harm of chemical fertilizer can be reduced.

\section{References}

[1] Adeniran, J.A., L.B. Taiwo and R.A. Sobulo, 2003. Effects of Organic wastes and Method of composting on compost maturity, Nutrient Composition of Compost and Yields of Two Vegetable Crops. J. of Sustainable Agriculture, Vol. 22: 95-101.

[2] A.O.A.C., 1994. Official Methods of Analysis Association of an Official Analytical Chemists. 14th Edition- Washington D.C. USA

[3] Barnett, E.A and B.H. Hunter, 1980. Illustrated Genera of Imperfect Fungi. Bruges Publishing Company, Minneapolis, Pg: 13-55.

[4] Betts WB, dart, RK (1988) biodegradation of lignin related compound by Aspergillus flavus.J.Gen.Micro.134:2413-2420

[5] Blanc, M., L. Marilley, T. Beffa and M. Aragno, 1997. Rapid Identification of Heterotrophic, Thermophilic, Spore forming Bacteria Isolated from Hot Composts. Int. J. Syst. Bacterial, 47: 1246-6496.

[6] Christensen BT (1985). Wheat and Barley straw decomposition under field condition. Effect of soil type and plant cover on weight loss, nitrogen and potassium content. Soil boil.biochem.17:691-697

[7] Comparative effect of cow dung manure on soil and leaf nutrient and yield of peeper, B.S Eusalo, K.O Hassan and S.O Ojeniyi(2002)

[8] Crop Growth. In: Agboola et al. (Eds) Proceedings of the 23rd All African Soil Science Conference, Pg: 38339. Ibadan. August 29-September 2, 1995.

[9] Cruickshank, R., J.P. Duguid, B.P. Marmion and R.W. Swain, 1973. Medical Microbiology, a Guide to Laboratory Diagnosis and Guide of Infection. Longman Publisher.

[10]D.V. Adegunloye et al (2007) Microbial Analysis of Compost Using Cowdung as Booster

[11]Gray, K.R. and A.J. Briddlestone, 1981. The Composting of Agricultural Wastes. In: B Stoneho (Ed) Biological Husbandry. Butterworths Publications. London, England. Pg: 99-112.

[12]Foth, H.O., 1980. Fundamentals of Soil Science. John Willey and Sons Inc Canada, Pg: 157-166.

[13] Falcon MA,Rodriguez A,carnicero A,Regalado V,perestelo F,Milstein O,fuente GL (1995.Isolation of microorganisms with lignin transformation potential from soil of tenirife island boil.biochem.27:121-126.

[14] Gray, K.R. and A.J. Briddlestone, 1981. The Composting of Agricultural Wastes. In: B Stoneho (Ed) Biological Husbandry. Butterworths Publications. London, England. Pg: 99-112.

[15] Hargerty, D.J., J.L. Pavoni and J.E. Heer, 1999. Solid Waste Management. Van Nostrand Reinhold New York. Pg: 12-13.

[16] Heisey P.W.and Moungi ,W.1996.Fertilizer Use and Maize Production in Sub Saharan Africa.CIMMYT Economics Working paper 96-01, CIMMYT,Mexico.

[17] Jackson, M.L. Soil chemical analysis, prentice Hall of India Pvt. Ltd., New Delhi (1973)

[18] Jeevan Rao, K. Ch. S. Rama Lakshmi and A. Sreenivasa Raju Evaluation of Manurial value in Urban and Agricultural Waste Composts. Journal of the Indian Society of Soil Science (in press)(2007) 


\section{International Journal of Science and Research (IJSR) \\ ISSN (Online): 2319-7064 \\ Index Copernicus Value (2015): 78.96 | Impact Factor (2015): 6.391}

[19] John, N.M., G.O. Adeoye and M.K.C. Shridhar, 1995. Effect of a Binding Agent and Sawdust Amendment on the Stabilization of Compost.

[20] K.Nagasaki,N.Akakura,K.Atsumi,"degradation pattern of organic material in batch and fed-batch composting operation,"1988,waste Manage,Res.15,484-489

[21] Milner, B.A. and P.J. Whiteside, 1984. Introduction to Atomic Absorption Spectrophotometer. 3rd Edition Pye Unicam Ltd, York Street, Cambridge England.Pg: 52.

[22] Murray, P.R., W.L. Drew, G.S. Kobayashi and J.H. Thompson, 1990. Medical Microbiology, Wolfe Publisher Ltd. Pg: 13-55.

[23] Maheshwari, H.A.1914 and Balasubramanyam, P.V.1998.Simultaniousy thermophilic fungi utilization of glucose and sucrose J.Bacterio (170:3274-3280)

[24] N.Sasaki,K.I.Suehara,J.Kohda,Y.Nakano,T.yang,'Effec $\mathrm{t}$ of $\mathrm{C}: \mathrm{N}$ ratio and $\mathrm{pH}$ of raw material and oil degradation efficiency in a compost fermentation process,"2003,Journal of bioscience and bioengineering 96,47-52

[25] Priti joshi, 2001, jaivik khad tantragyan, Bhopal.

[26] Rhode, B. and G. Hartman, 2002. Introducing Mycology by examples. Scheing Aktiengesell Shaft Press Hamb

[27] Rasal P.H., Kalbhor H.B., Shingte V.V and Patil P.L. Development of technology for rapid composting and enrichment. In: Biofertilizers - Potentialities and problems Sen, S.P and Patil P(Ed) pp. 254-258(1988).

[28] Salvator, K. and W.E. Sabee, 1995. Evaluation of Fertilizer Value and Nutrient Release from Corn and Soybean Residues under Laboratory and Greenhouse. Conditions. Commu. Soil/ Sci., Plant Anal., 26: 469484.

[29] Smith, L.N. and W.E. Wheeler, 1979. Nutritional and Economic Value of Anim. Excreta. J. Anim. Sci., 48 Pg: 14-15.

[30] Stainer, A., R. Levi-Minzi and R. Riffaldi, 1998. Maturity Evaluation of Organic Wastes. Biocycle, 29: 54-56

[31] Sadasivam S \& Manickam, A Biochemical Methods, New Age International (P) Ltd., Publishers, $2^{\text {nd }}$ Edn. (1996)

[32] Shinde P.H., Naik K.L., Nazirker R.B., Kadam, S.K and Khaire V.M Evaluation of Vermicompost .Proceedings of the National Seminar on Organic Farming M.P.K.V, Pune pp.54-55(1992).

[33] Serial dilution method- K.R. Aneja Walkley, J and Riley, J. P. 1962. A critical examination of a rapid method for determining organic carbon in soils: Effects of variation in digestion conditions and of organic carbon constituents. Soil Sci. 63: 251-263 